\title{
Induction and antiviral activity of human $\beta$-defensin 3 in intestinal cells with picornavirus infection
}

\author{
W. CHEN, Z. LIU, Q. ZHANG, Q. YAN, S. JING* \\ Medical School, Kunming University of Science and Technology, Kunming, P. R. China
}

Received October 5, 2017; revised December 12, 2017; accepted July 9, 2018

\begin{abstract}
Summary. - Antimicrobial peptides produced by epithelial and immune cells protect tissues from various infections. Whether enterovirus infection leads to stimulation of antimicrobial peptide expression is unknown. We examined antimicrobial peptide mRNA and protein production in HT-29 colon adenocarcinoma cells infected with picornaviruses. The antiviral activity of increased antimicrobial peptide production was evaluated by using a recombinant peptide and corresponding gene overexpression. Enterovirus infection enhanced both the mRNA expression and secretion of human $\beta$-defensin (hBD) 3 in intestinal epithelial cells but did not increase expression of human neutrophil peptide 1-3 (HNP 1-3), HNP4, human defensin 5 (HD5), HD6, hBD1, hBD2, and hBD5. The recombinant but not the intracellularly overexpressed hBD3 inhibited enterovirus (EV) 71, coxsackievirus A16 (CVA16), CVB5 and poliovirus 1 (PV1) infecting HT-29 cells. Our results suggest that enterovirus infection induces hBD3 production in human intestinal epithelial cells and that hBD3 can exert extracellular anti-enterovirus activity.
\end{abstract}

Keywords: enterovirus; human $\beta$-defensin 3; intestinal epithelial cells; antiviral activity

\section{Introduction}

Defensins are small, cysteine-rich, cationic peptides with $\beta$-pleated sheet structures found in mammalian tissues. They are active against bacteria, fungi and many viruses as host defense peptides. Defensins consist of 18-45 amino acids including six (in vertebrates) to eight conserved cysteine residues. There are three subfamilies in mammalian cells: $\alpha-, \beta$ - and $\theta$-defensins. They differ in disulfide bonds between the six conserved cysteine residues (Klotman and Chang, 2006).

Human a-defensin 1-, a-defensin 2-, a-defensin 3and $\alpha$-defensin 4 -designated human neutrophil peptides (HNP1, HNP2, HNP3 and HNP4) are mainly expressed by neutrophils. They are also expressed constitutively by other

*Corresponding author. E-mail: jingshenrong@kmust.edu.cn; phone: + 86-87165920776.

Abbreviations: CVA16 = coxsackievirus A16; CVB5 = coxsackievirus $\mathrm{AB} 5 ; \mathrm{EV}=$ enterovirus; $\mathrm{hBD}=$ human $\beta$-defensin; $\mathrm{HD}=$ human defensin; HFMD = hand, foot and mouth disease; $\mathrm{HNP}=$ human neutrophil peptide; $\mathrm{PV}=$ poliovirus immune cells, such as monocytes, macrophages, natural killer cells, B cells and $\gamma \delta$ T cells. HNP1, HNP2 and HNP3 differ only in the first amino acid, while human $\alpha$-defensins HD5 and HD6 are constitutively or inductively expressed in intestinal tract, female genital tract and other organs (Klotman and Chang, 2006). Human $\beta$-defensin 1 (hBD1), hBD2, hBD3, hBD4, hBD5 and hBD6 are expressed mainly by epithelial cells (Ganz, 2003; Yang et al., 2004). The hBD1 is constitutively expressed by epithelial cells. However, expression of hBD2 and hBD3 can be induced by microbes and their products such as endotoxins (Duits et al., 2003; Sorensen et al., 2005).

It has been reported that some defensins either inhibit or enhance enveloped viruses (HIV, HSV, IAV, RSV, PIV, VSV, CMV, etc.) when participating at attachment, fusion or entry, and they can even block viral nuclear import as well as transcription within infected cells (Ding et al., 2009). Virus replication of non-enveloped viruses, such as BK virus, human adenovirus and papilloma virus is inhibited by HNP1, HD5 and hBD1 (Ding et al., 2009). Human rhinovirus induces hBD2 expression in the infected respiratory tract and increases hBD2 and hBD3 mRNA expression in 
cultured bronchial epithelial cells (Duits et al., 2003; Proud et al., 2004). Mouse $\beta$-defensin 3 was reported to possess anti-coxsackievirus B3 (CVB3) activity in HeLa cells and to protect mice from myocarditis induced by CVB3 infection (Jiang et al., 2015). However, whether human enteroviruses increase human defensin expression in intestinal epithelial cells and whether defensins affect enterovirus infection remains unclear. Here, we report that hBD3 is induced, expressed and secreted in HT-29 cells infected with enterovirus coxsackievirus CVA16, CVB5 and enterovirus 71 (EV71), the main etiological agents of hand, foot and mouth disease (HFMD), and poliovirus 1 (PV1). The extracellular activity of hBD3 against enterovirus infection demonstrated extracellular antiviral activity.

\section{Materials and Methods}

Cells, viruses and reagents. HT-29 colon adenocarcinoma cells (ATCC ${ }^{\oplus} \mathrm{HTB}-38^{\mathrm{ma}}$ ) were maintained in DMEM (GIBCO, UK) containing 10\% fetal bovine serum (FBS, GIBCO). Enterovirus type 71 (EV71), coxsackievirus A16 (CVA16) and B5 (CVB5) were isolated from the clinical stool samples of patients with HMFD. Poliovirus type 1 (PV1) was purchased from the China Center for Type Culture Collection (CCTCC, China). The recombinant hBD3 (ab200245), the anti-hBD3 antibody (ab109572) and the anti-GAPDH antibody (ab8245) were purchased from Abcam (China).

RNA extraction, RT-PCR. Total RNA was extracted using Mini BEST universal RNA extraction kit (TAKARA, China) and reversetranscribed into first strand cDNA using the PrimeScript reversetranscriptase (TAKARA). Primers for RT-PCR of defensin genes are shown in Table 1 (Erhart et al., 2011; Hsu et al., 2011).

Construction of recombinant vectors and transfection. The hBD3 cDNA with or without its signal sequence was amplified using primers in Table 1. The genes were cloned into pcDNA3.1 and designated as pcDNA3.1-shBD3 (with signal peptide), pcDNA3.1hBD3 (without signal peptide) and validated by DNA sequencing. Transfection of the plasmids into HT-29 cells was performed using polyethylenimine (PEI) (Polysciences, USA) following the manufacturer's instructions.

ELISA and Western blot. For hBD3 quantification, $5 \mathrm{ml}$ of cell culture supernatants were collected, lyophilized and then resolved in $0.5 \mathrm{ml}$ of $\mathrm{PBS}$. The hBD3 production was measured by the Human BD-3 mini ABTS ELISA development kit (PEPROTECT, USA) in accordance with the manufacturer's instructions. For Western blot analysis, cell lysates were resolved by $10 \%$ SDS-PAGE and then transferred onto PVDF membranes by electrophoretic transfer (Sangon Biotech, China). Membranes were blocked using 5\% non-fat milk in TPBS (pH 7.2) and incubated with antibodies against $\mathrm{hBD} 3$ and GAPDH. The proteins were detected by reaction with anti-mouse HRP conjugate (Abcam) followed
Table1. The Primers for PCR of defensin genes

\begin{tabular}{|c|c|c|}
\hline Genes & Primers $\left(5^{\prime}-3^{\prime}\right)$ (forward/reverse) & Sizes \\
\hline \multirow{2}{*}{ HNP1-3 } & 5'-GCAGCGGACATCCCAGAAGT-3' & \multirow{2}{*}{$266 \mathrm{bp}$} \\
\hline & 5'-AAGGAAATTGAGCAGAAGGTACAG GA-3' & \\
\hline \multirow{2}{*}{ HNP4 } & 5'-ATGAGGATTATCGCCCTCC-3' & \multirow{2}{*}{$294 \mathrm{bp}$} \\
\hline & 5'-TTAATCGACACGCGTGC-3' & \\
\hline \multirow{2}{*}{ HD5 } & 5'- GCCATCCCTGCTGCCATTC-3' & \multirow{2}{*}{$241 \mathrm{bp}$} \\
\hline & 5'-AGATTTCACACCCCGGAG-3' & \\
\hline \multirow{2}{*}{ HD6 } & 5'-ATGAGAACCCTCACCATCC-3' & \multirow{2}{*}{$303 \mathrm{bp}$} \\
\hline & 5'-TCAGAGGCAGCAGAATC-3' & \\
\hline \multirow{2}{*}{ hBD1 } & 5'-TTGTCTGAGATGGCCTCAGGTGGTAAC-3' & \multirow{2}{*}{$253 \mathrm{bp}$} \\
\hline & 5'-ATACTTCAAAAGCAATTTTCCTTTAT-3' & \\
\hline \multirow{2}{*}{ hBD2 } & 5'-ATCAGCCATGAGGGTCTTGT-3' & \multirow{2}{*}{$173 \mathrm{bp}$} \\
\hline & 5'-GAGACCACAGGTGCCAATTT-3' & \\
\hline \multirow{2}{*}{ hBD3 } & 5'-ATGAGGATCCATTATCTTC-3' & \multirow{2}{*}{$192 \mathrm{bp}$} \\
\hline & 5'-TCGGCAGCATTTTCGGCC-3' & \\
\hline \multirow{2}{*}{ hBD5 } & 5'-ATGGCCCTGATCAGGAAGAC-3' & \multirow{2}{*}{$237 \mathrm{bp}$} \\
\hline & 5'-TCAGATCCTCTGTCTGC-3' & \\
\hline \multirow{2}{*}{ GAPDH } & 5'-CCATGGCACCGTCAAGGCTGA-3' & \multirow{2}{*}{$533 b p$} \\
\hline & 5'-TTG GCAGTGGGGACACGGAA-3' & \\
\hline \multirow[t]{9}{*}{ hBD3 } & P1 (sense), 5'-GGGGTACCATGAGGATCCAT- & \\
\hline & TATCTTCT-3' & \\
\hline & (with signal sequence, Kpn i site underlined) & \\
\hline & P3 (sense), 5'-GGGGTACCACCATGGCTAGAG & \\
\hline & GATCCATTATCTT-3' (without signal sequence, & \\
\hline & Kpn i site underlined) & \\
\hline & P2 (anti-sense): 5'-CGGAATTCTTAGTGGTGG & \\
\hline & GGTGGTGGTGTTTCTTTCTTCGGCAGCAT-3’ & \\
\hline & (EcoR i site underlined and 6HIS-tag) & \\
\hline
\end{tabular}

by ECL substrate (Merck Millipore, USA) and signal detection using X-ray film.

Infection, growth and titration of infectious enterovirus. HT-29 cells were grown in DMEM medium supplemented with $10 \%$ FBS. When the cells were approximately at $80 \%$ confluence, the virus, hBD3 alone, or a mixture of both was added to HT-29 cells for $2 \mathrm{~h}$. Cells were washed twice with PBS, and then fresh DMEM supplemented with $2 \%$ FBS was added and the cells were further cultured at $37^{\circ} \mathrm{C}$ with $5 \% \mathrm{CO}_{2}$ for $72 \mathrm{~h}$. To evaluate hBD3 inhibition of intracellular viral replication, we cloned the hBD3 gene with or without the signal sequence into plasmid pcDNA3.1 and extracellularly or intracellularly expressed hBD3 protein in HT29 cells. HT-29 cells were transfected with pcDNA3.1-shBD3 or pcDNA3.1-hBD3 and after $48 \mathrm{~h}$ infected with EV71.

To determine infectious titer of viruses, HT- 29 cells were plated onto 96 -well plates $\left(5 \times 10^{3}\right.$ cells/well). Diluted viral stock $\left(10^{-1}\right.$ to $10^{-8} ; 0.1 \mathrm{ml}$ ) was added to each well and incubated for $2 \mathrm{~h}$, followed by replacement with $0.1 \mathrm{ml}$ of fresh DMEM supplemented with $2 \%$ FBS, and cultured for an additional 7 days. The viral titer was calculated as $\mathrm{TCID}_{50} / \mathrm{ml}$ using the Reed-Muench formula. 
(a)

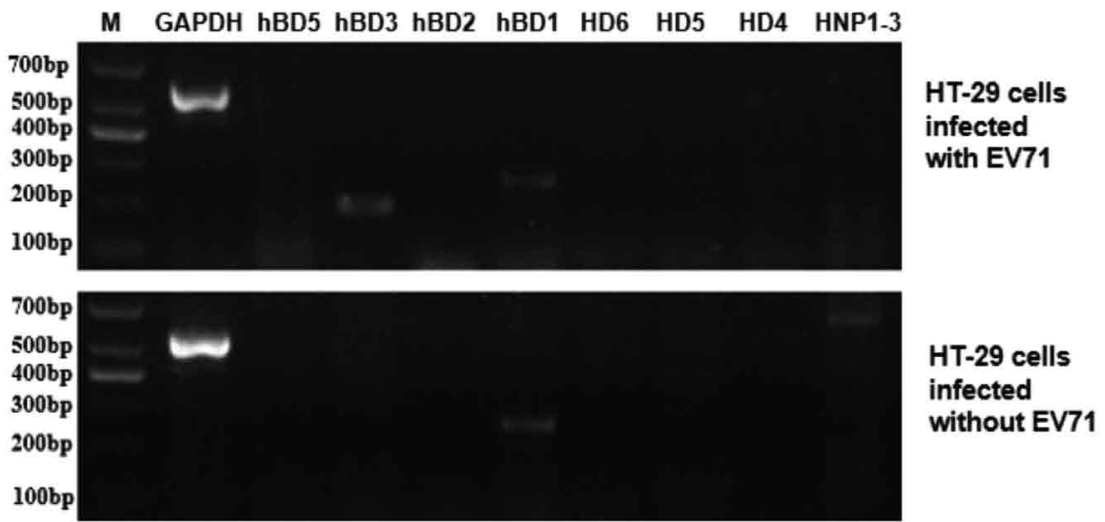

(b)

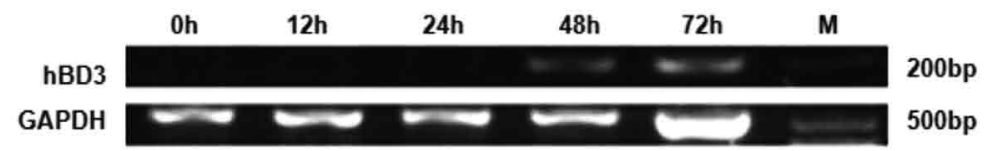

(c)

(d)
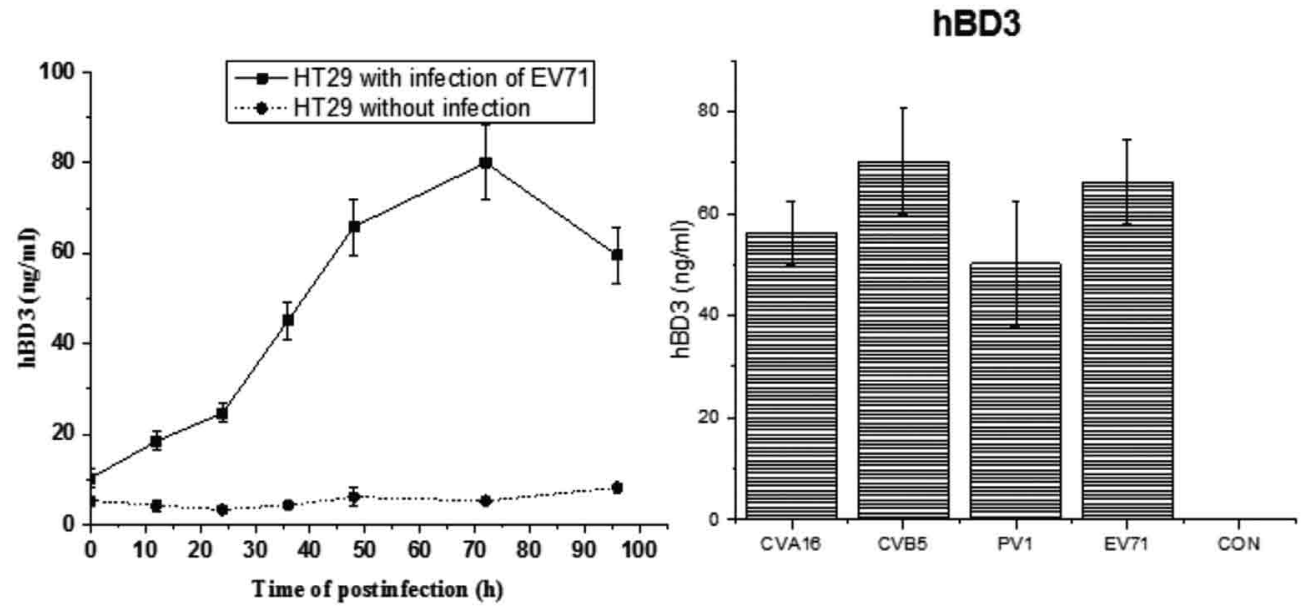

Fig. 1

Induction of hBD3 expression by picornaviruses

(a) RT-PCR for hBD5, hBD3, hBD2, hBD1, HD6, HD5, HNP4, HNP1-3, and human GAPDH mRNA of HT-29 cells after 48 h infection (top) or without (low) EV71 at MOI of 0.01; (b) RT-PCR for hBD3 and human GAPDH mRNA from HT-29 cells inoculated with EV71 at MOI of 0.01 after 12, 24, 48, $72 \mathrm{~h}$; (c) ELISA analysis of extracellular hBD3 from HT-29 cells infected with 0.01 MOI of EV71 after 12, 24, 36, 48 and 72 h; (d) ELISA of hBD3 in supernatant of HT-29 cells inoculated with CVA16, CVB5, PV1, and EV71 at MOI of 0.01 after $48 \mathrm{~h}$.

\section{Results}

Picornaviruses induce hBD3 expression and secretion in HT-29 cells

To investigate whether picornaviruses induce defensins production, we inoculated HT-29 cells with EV71. Three days later, the cells were harvested and tested for transcript expression of HNP1-3, HNP4, HD5, HD6, hBD1, hBD2, hBD3 and hBD 5 by RT-PCR. EV71 only induced hBD3 in HT-29 cells (Fig. 1a and 1d). Also, other viruses, CVA16,
CVB5 and PV1 induced the production of hBD3 as was proved by ELISA (Fig. 1d). The constitutively expressed hBD1 was expressed in both the experimental and control groups (Kaiser and Diamond, 2000). The rest of defensins were not expressed in EV71-infected HT-29 cells (Fig. 1a). Furthermore, the hBD3 was detected only after 48 h postinfection at MOI of 0.01 (Fig. 1b). ELISA showed that hBD3 was presented extracellularly after 24 h of EV71 infection (Fig. 1c). These results suggest that picornavirus infection could induce hBD3 production in intestinal epithelial cells. 
(a)

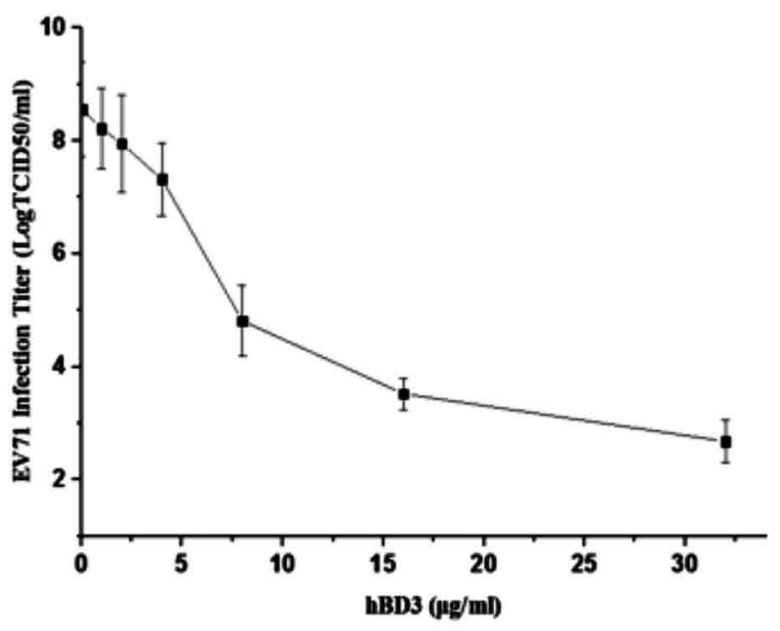

(b)

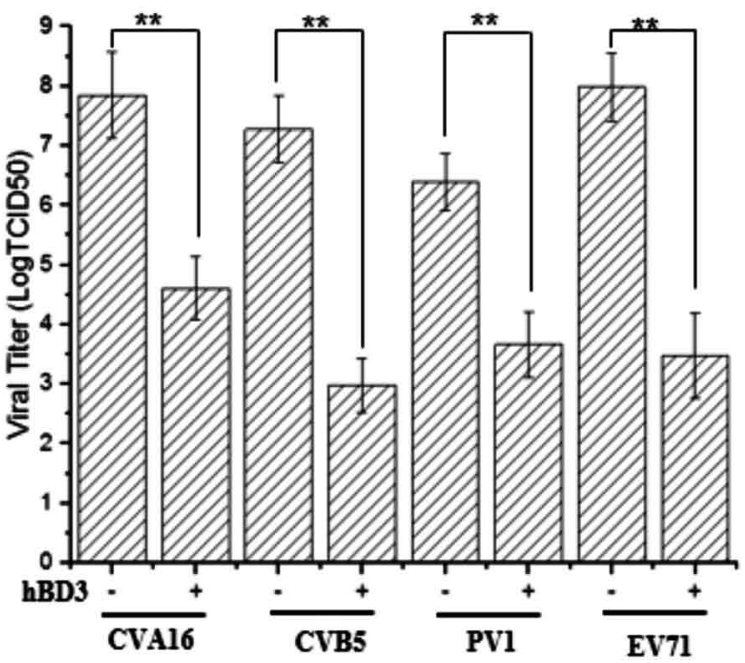

Fig. 2

The hBD3 suppressed picornaviruses replication

HT-29 cells ( $1 \times 10^{5}$ cells/well) were inoculated with EV71 at MOI of 0.01 in the presence of $0,1,2,4,8,16$ and $32 \mu \mathrm{g} / \mathrm{ml} \mathrm{hBD} 3$; (a) or EV71, CVA16, CVB5, and PV1 at MOI of 0.01 in the presence of $16 \mu \mathrm{g} / \mathrm{ml} \mathrm{hBD} 3$ for $2 \mathrm{~h}$; (b) HT-29 cells were harvested after $48 \mathrm{~h}$ post infection and the viral infective titers were determined $\left(\mathrm{TCID}_{50} / \mathrm{ml}\right)$. Data are from three independent experiments. Results are expressed as means $\pm \mathrm{SD}$. ${ }^{* *} \mathrm{p}<0.01$.

\section{The hBD3 suppresses virus growth}

To examine whether hBD3 possesses antiviral properties against picornaviruses, we studied the ability of hBD3 to inhibit picornavirus infection. The experimental results are shown in Fig. 2. In the control, the highest dose of $32 \mu \mathrm{g} / \mathrm{ml}$ hBD3 was not cytotoxic to HT-29 cells (data not shown). The infectious titer of EV71 was decreased with increasing concentration of hBD3 treatment (Fig. 2a). Also, hBD3 inhibited infectious titers of CVA16, CVB5 and PV1 (Fig. 2b). These results indicate that hBD3 possesses potent antiviral activity against picornaviruses.

\section{The hBD3 extracellularly inhibits viral infection}

The previous study reported that hBD3 suppresses cellular entry of vesicular stomatitis virus (VSV) (Mausumi Basu and Amiya K Banerjee, 2010). It is not clear whether hBD3 blocks picornavirus cellular entry or inhibits viral replication intracellularly. As shown in Fig. 3, by using the ORF vector without the signal domain, overexpressed intracellular hBD3 did not suppress EV71 replication. In contrast, EV71 infective titer decreased when the virus was pre-treated with recombinant $\mathrm{hBD} 3$ or after transfection of the $\mathrm{hBD} 3$ gene containing signal sequence. The results show that hBD3 blocked EV71 entry into host cells.

\section{Discussion}

The hBD3 is a peptide of 45 amino acids with a molecular mass of $5 \mathrm{kDa}$, and a conserved six-Cys motif (García et al., 2001a; Harder et al., 2001). hBD3 can be expressed in the respiratory, gastrointestinal and genitourinary tracts, in skin and tonsils (Harder et al., 2001). The hBD3 can be expressed in Staphylococcus aureus, by induction with TNF- $\alpha$, EGF, and phorbol 1,2-myristate 1,3-acetate (PMA) (García et al., 2001a; Harder et al., 2001; Jia et al., 2001; Kawsar et al., 2009). Here, we report that picornaviruses, including EV71, CVA16, CVB5 and PV1 can induce only hBD3 expression in HT-29 cells, but not HNP1-3, HNP4, HD5, HD6, hBD1, hBD2, and hBD5. A previous study showed that HNP1-3 and HNP4 are expressed constitutively in lymphocytes, but not epithelial cells (Ding et al., 2009). The HD5 and HD6 may constitutively or inductively be expressed in intestinal Paneth cells and vaginal epithelial cells (Ding et al., 2009). However, the expression of HD5 and HD6 were not induced in HT-29 cells by EV71 infection in our study. Human $\beta$-defensins are expressed mainly by epithelial cells (Yang et al., 2004). The hBD1 expression is constitutive in epithelial and blood cells (Kaiser and Diamond, 2000; Klotman and Chang, 2006). The hBD2 expression can be induced by pathogens and pro-inflammatory cytokines (Ding et al., 2009). Expression of hBD4 and hBD5 is induced in testes, gastric antrum, keratinocytes, osteoarthritic knee meniscus, and respiratory epithelial cells (García et al., 2001b; 
(a)

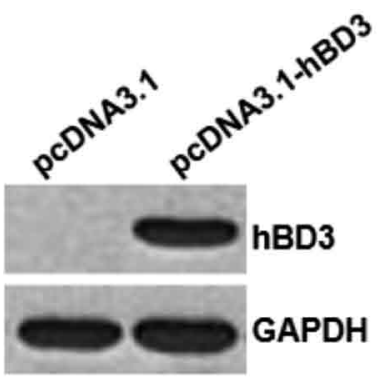

(b)

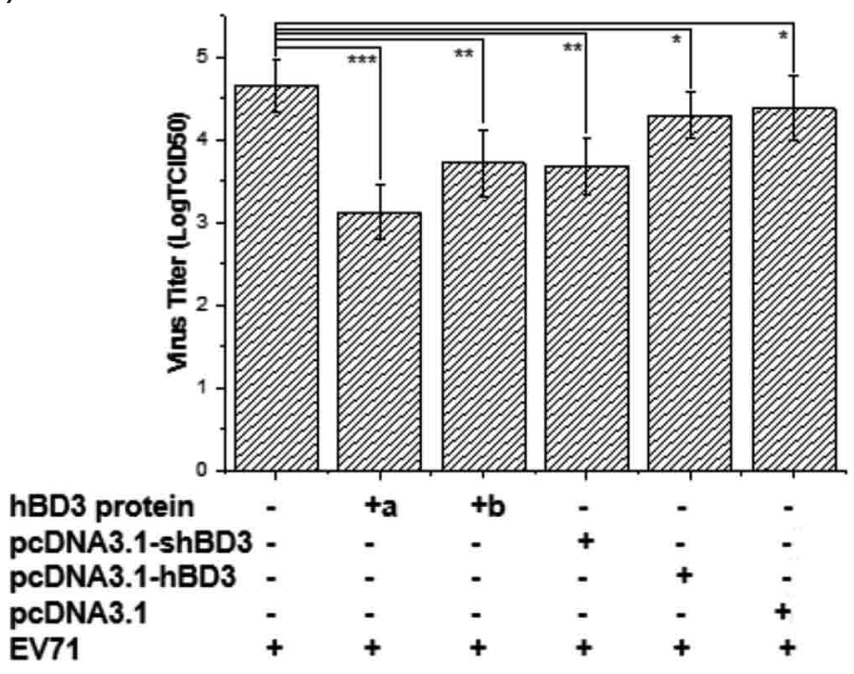

Fig. 3

The hBD3 extracellularly inhibits picornavirus infection

(a) The hBD3 gene without signal sequence was cloned into pcDNA3.1 and transfected into HT-29 cells. The expression was analyzed by western blot at $48 \mathrm{~h}$ after transfection; (b) $10^{5}$ cells HT-29 transfected with $10 \mu \mathrm{g}$ of pcDNA3.1-shBD3, pcDNA3.1-hBD3 and pcDNA3.1 were inoculated with EV71.

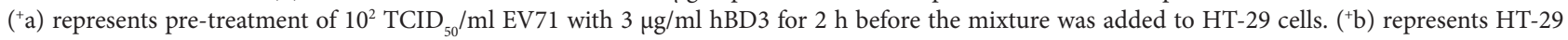
cells with both $10^{2} \mathrm{TCID}_{50} / \mathrm{ml} \mathrm{EV71} \mathrm{and} 3 \mu \mathrm{g} / \mathrm{ml} \mathrm{hBD} 3$. The viral infective titers were measured at $24 \mathrm{~h}$ after infection. Data are from three independent experiments and shown as means $\pm \mathrm{SD} .{ }^{*} \mathrm{p}>0.05,{ }^{* *} \mathrm{p}<0.05,{ }^{* *} \mathrm{p}<0.01$.

Musumeci et al., 2012; Noronha et al., 2014; Pierson et al., 2013; Yamaguchi et al., 2002). In the present study, expression of hBD2 and hBD5 was not induced in EV71-infected HT29 cells. This suggests that different defensins are induced in tissues by different pathogens.

In pathogenic infections, Toll-like receptors (TLR2, TLR3, TLR4, TLR5) were reported to be involved in the induction of human defensins expression (Chalifour et al., 2004; Duits et al., 2003; Nagy et al., 2005; Pivarcsi et al., 2005; Proud et al., 2004; Schaefer et al., 2005). Poly I:C, the agonist of TLR3, can also induce the production of hBD3 (Proud et al., 2004). Activated nucleotide-binding and oligomerization domain (NOD)-like receptors (NLRs) induce the expression of hBD3 (Ebersole et al., 2015). Analysis of the upstream region of the hBD3 promoter showed that there are no NF- $\kappa B$ consensus elements, but several consensus sequences of response elements for activator protein1 (AP-1), gamma interferon, GM-CSF, and NF-IL-6 (Jia et al., 2001). This suggested that inflammatory cytokines produced by innate immune cells after viral infection may lead to hBD3 induction. It was reported that the increased cytokine production of IL-1, IL-6 and TNF- $\alpha$ also up-regulated mRNA expression of TLR2, TLR7 and TLR8 in EV71-infected cells (Gong et al., 2012). Therefore, we postulate that increased $\mathrm{hBD} 3$ expression in the enterovirus infection may be mediated by proinflammatory cytokines, which are induced by interactions of picornaviruses with TLRs.
The hBD3 possess a broad spectrum of antimicrobial activity against many pathogenic microbes, including Grampositive and Gram-negative bacteria, fungi (Batoni et al., 2006), and different viruses such as HIV, IAV, VSV, HBV, HPV, HSV, CVB3 and vaccinia virus (Ding et al., 2009; Hazrati et al., 2006; Jiang et al., 2015; Wilson et al., 2013). It is involved in different infectious diseases progress and immune regulations (Bian et al., 2016; Li et al., 2016; Szekeres et al., 2016; Wanke et al., 2016; Xu et al., 2016). It has been reported that hBD3 can block IAV, HSV, and HIV entry into cells by cross linking and immobilizing viral surface proteins (Hazrati et al., 2006; Leikina et al., 2005; Quinones-Mateu et al., 2003). In this study, the antiviral activity of hBD3 was examined. Our results demonstrate that hBD3 displayed potent extracellular antiviral activity against picornaviruses. These data indicate that hBD3 blocks picornavirus entry into host cells and may play a crucial role in the initial defense reaction of intestinal cells against invading enteroviruses.

In conclusion, we here demonstrate that $\mathrm{hBD} 3$ expression is induced by picornavirus infection in intestinal epithelial cells, which in turn may inhibit viral infection extracellularly. Our findings provide a new direction for further development toward an anti-enterovirus infection approach in the intestinal tract.

Acknowledgments. This research is supported by Grants of Yunnan Provincial Department of Education (2017ZZ138). We 
thank Professor Zhaoqing Yang (Institute of Medical Biology, Chinese Academy of Medical Science) for critical reading of this manuscript.

\section{References}

Batoni G, Maisetta G, Esin S, Campa M (2006): Human beta-defensin-3: a promising antimicrobial peptide. Mini Rev. Med. Chem. 6, 1063-1073. https://doi. org/10.2174/138955706778560193

Bian T, Li L, Lyu J, Cui D, Lei L, Yan F (2016): Human $\beta$-defensin 3 suppresses Porphyromonas gingivalis lipopolysaccharideinduced inflammation in RAW 264.7 cells and aortas of ApoE-deficient mice. Peptides 82, 92-100. https://doi. org/10.1016/j.peptides.2016.06.002

Chalifour A, Jeannin P, Gauchat JF, Blaecke A, Malissard M, N'Guyen T, Thieblemont N, Delneste Y (2004): Direct bacterial protein PAMP recognition by human NK cells involves TLRs and triggers alpha-defensin production. Blood 104, 1778-1783. https://doi.org/10.1182/blood2003-08-2820

Ding J, Chou YY, Chang TL (2009): Defensins in viral infections. J. Innate. Immun. 1, 413-420. https://doi. org/10.1159/000226256

Duits LA, Nibbering PH, van Strijen E, Vos JB, Mannesse-Lazeroms SP, van Sterkenburg MA, Hiemstra PS (2003): Rhinovirus increases human beta-defensin-2 and -3 mRNA expression in cultured bronchial epithelial cells. FEMS Immunol. Med. Microbiol. 38, 59-64. https://doi.org/10.1016/ $\underline{\text { S0928-8244(03)00106-8 }}$

Ebersole JL, Kirakodu S, Novak MJ, Exposto CR, Stromberg AJ, Shen S, Orraca L, Gonzalez-Martinez J, Gonzalez OA (2015): Effects of aging in the expression of NOD-like receptors and inflammasome-related genes in oral mucosa. Mol. Oral Microbiol. 31, 18-32. https://doi.org/10.1111/ omi.12121

Erhart W, Alkasi O, Brunke G, Wegener F, Maass N, Arnold N, Arlt A, Meinhold-Heerlein I (2011): Induction of human beta-defensins and psoriasin in vulvovaginal human papillomavirus-associated lesions. J. Infect. Dis. 204, 391-399. https://doi.org/10.1093/infdis/jir079

Ganz T (2003): Defensins: antimicrobial peptides of innate immunity. Nat. Rev. Immunol. 3, 710-720. https://doi. org/10.1038/nri1180

García JR, Jaumann F, Schulz S, Krause A, Rodríguez-Jiménez J, Forssmann U, Adermann K, Klüver E, Vogelmeier C, Becker D, Hedrich R, Forssmann WG, Bals R (2001a): Identification of a novel, multifunctional beta-defensin (human beta-defensin 3) with specific antimicrobial activity. Its interaction with plasma membranes of Xenopus oocytes and the induction of macrophage chemoattraction. Cell Tissue Res. 306, 257-264. https://doi.org/10.1007/ $\underline{\text { s004410100433 }}$

García JR, Krause A, Schulz S, Rodríguez-Jiménez FJ, Klüver E, Adermann K, Forssmann U, Frimpong-Boateng A, Bals R, Forssmann WG (2001b): Human beta-defensin 4: a novel inducible peptide with a specific salt-sensitive spectrum of antimicrobial activity. FASEB J. 15, 1819-1821. https:// doi.org/10.1096/fj.00-0865fje

Gong X, Zhou J, Zhu W, Liu N, Li J, Li L, Jin Y, Duan Z (2012): Excessive proinflammatory cytokine and chemokine responses of human monocyte-derived macrophages to enterovirus 71 infection. BMC Infect. Dis. 12, 224. https:// doi.org/10.1186/1471-2334-12-224

Harder J, Bartels J, Christophers E, Schroder JM (2001): Isolation and characterization of human beta-defensin-3, a novel human inducible peptide antibiotic. J. Biol. Chem. 276, 5707-5713. https://doi.org/10.1074/jbc.M008557200

Hazrati E, Galen B, Lu W, Wang W, Ouyang Y, Keller MJ, Lehrer RI, Herold BC (2006): Human alpha- and beta-defensins block multiple steps in herpes simplex virus infection. J. Immunol. 177, 8658-8666. https://doi.org/10.4049/ jimmunol.177.12.8658

Hsu GJ, Tzang BS, Tsai CC, Chiu CC, Huang CY, Hsu TC (2011): Effects of human parvovirus B19 on expression of defensins and Toll-like receptors. Chin. J. Physiol. 54, 367-376.

Jia HP, Schutte BC, Schudy A, Linzmeier R, Guthmiller JM, Johnson GK, Tack BF, Mitros JP, Rosenthal A, Ganz T, McCray PB $\operatorname{Jr}$ (2001): Discovery of new human beta-defensins using a genomics-based approach. Gene 263, 211-218. https:// doi.org/10.1016/S0378-1119(00)00569-2

Jiang Y, Zhu R, Luo L, Mu Q, Zhu Y, Luo H, Zou X, Shen X (2015): Recombinant mouse $\beta$-defensin 3 protects against coxsackievirus B3-induced myocarditis in mice. Intervirology 58, 343-349. https://doi.org/10.1159/000442588

Kaiser V, Diamond G (2000): Expression of mammalian defensin genes. J. Leukoc. Biol. 68, 779-784.

Kawsar HI, Weinberg A, Hirsch SA, Venizelos A, Howell S, Jiang B, Jin G (2009): Overexpression of human beta-defensin-3 in oral dysplasia: potential role in macrophage trafficking. Oral Oncol. 45, 696-702. https://doi.org/10.1016/j. oraloncology.2008.10.016

Klotman ME, Chang TL (2006): Defensins in innate antiviral immunity. Nat. Rev. Immunol. 6, 447-456. https://doi. org/10.1038/nri1860

Leikina E, Delanoe-Ayari H, Melikov K, Cho MS, Chen A, Waring AJ, Wang W, Xie Y, Loo JA, Lehrer RI, Chernomordik LV (2005): Carbohydrate-binding molecules inhibit viral fusion and entry by crosslinking membrane glycoproteins. Nat. Immunol. 6, 995-1001. https://doi.org/10.1038/ni1248

Li L, Bian T, Lyu J, Cui D, Lei L, Yan F (2016): Human $\beta$-defensin-3 alleviates the progression of atherosclerosis accelerated by Porphyromonas gingivalis lipopolysaccharide. Int. Immunopharmacol. 38, 204-213. https://doi.org/10.1016/j. intimp.2016.06.003

Mausumi Basu SK, Amiya K Banerjee SB (2010): Role of human beta defensin 3 during type i interferon mediated antiviral response against vesicular stomatitis virus. Int. J. Interferon Cytokine Mediat. Res. 2, 23-32.

Musumeci G, Carnazza ML, Leonardi R, Loreto C (2012): Expression of $\beta$-defensin- 4 in "an in vivo and ex vivo model" of human osteoarthritic knee meniscus. Knee Surg. Sports Traumatol. Arthrosc. 20, 216-222. https://doi. org/10.1007/s00167-011-1630-x 
Nagy I, Pivarcsi A, Koreck A, Széll M, Urbán E, Kemény L (2005): Distinct strains of Propionibacterium acnes induce selective human beta-defensin-2 and interleukin- 8 expression in human keratinocytes through toll-like receptors. J. Invest. Dermatol. 124, 931-938. https://doi. org/10.1111/j.0022-202X.2005.23705.X

Noronha SA, Noronha SM, Lanziani LE, Ipolito MZ, Ferreira LM, Gragnani A (2014): Human beta defensin-4 and keratinocyte growth factor gene expression in cultured keratinocyte and fibroblasts of burned patients. Acta Cir. Bras. 29 (Suppl. 3), 39-43. https://doi.org/10.1590/S0102$\underline{86502014001700008}$

Pierson T, Learmonth-Pierson S, Pinto D, van Hoek ML (2013): Cigarette smoke extract induces differential expression levels of beta-defensin peptides in human alveolar epithelial cells. Tob. Induc. Dis. 11, 10. https://doi. org/10.1186/1617-9625-11-10

Pivarcsi A, Nagy I, Koreck A, Kis K, Kenderessy-Szabo A, Szell M, Dobozy A, Kemeny L (2005): Microbial compounds induce the expression of pro-inflammatory cytokines, chemokines and human beta-defensin-2 in vaginal epithelial cells. Microbes Infect. 7, 1117-1127. https://doi. org/10.1016/j.micinf.2005.03.016

Proud D, Sanders SP, Wiehler S (2004): Human rhinovirus infection induces airway epithelial cell production of human beta-defensin 2 both in vitro and in vivo. J. Immunol. 172, 4637-4645. https://doi.org/10.4049/ jimmunol.172.7.4637

Quinones-Mateu ME, Lederman MM, Feng Z, Chakraborty B, Weber J, Rangel HR, Marotta ML, Mirza M, Jiang B, Kiser P, Medvik K, Sieg SF, Weinberg A (2003): Human epithelial beta-defensins 2 and 3 inhibit HIV-1 replication. AIDS 17, F39-48. https://doi.org/10.1097/00002030200311070-00001

Schaefer TM, Fahey JV, Wright JA, Wira CR (2005): Innate immunity in the human female reproductive tract: antiviral response of uterine epithelial cells to the TLR3 agonist
poly(I:C). J. Immunol. 174, 992-1002. https://doi. org/10.4049/jimmunol.174.2.992

Sorensen OE, Thapa DR, Rosenthal A, Liu L, Roberts AA, Ganz $\mathrm{T}$ (2005): Differential regulation of beta-defensin expression in human skin by microbial stimuli. J. Immunol. 174, 4870-4879. https://doi.org/10.4049/ jimmunol.174.8.4870

Szekeres M, Ivitz E, Datki Z, Kálmán J, Pákáski M, Várhelyi ZP, Klivényi P, Zadori D, Somogyvári F, Szolnoki Z, Vécsei L, Mándi Y (2016): Relevance of defensin $\beta-2$ and $\alpha$ defensins (HNP1-3) in Alzheimer's disease. Psychiatry Res. 239, 342-345. https://doi.org/10.1016/j. psychres.2016.03.045

Wanke D, Mauch-Mücke K, Holler E, Hehlgans T (2016): Human beta-defensin-2 and -3 enhance pro-inflammatory cytokine expression induced by TLR ligands via ATP-release in a P2X7R dependent manner. Immunobiology 221, 1259-1265. https://doi.org/10.1016/j.imbio.2016.06.006

Wilson SS, Wiens ME, Smith JG (2013): Antiviral mechanisms of human defensins. J. Mol. Biol. 425, 4965-4980. https:// doi.org/10.1016/j.jmb.2013.09.038

Xu D, Zhang B, Liao C, Zhang W, Wang W, Chang Y, Shao Y (2016): Human beta-defensin 3 contributes to the carcinogenesis of cervical cancer via activation of NF-kB signaling. Oncotarget 7, 75902-75913. https://doi.org/10.18632/ oncotarget.12426

Yamaguchi Y, Nagase T, Makita R, Fukuhara S, Tomita T, Tominaga T, Kurihara H, Ouchi Y (2002): Identification of multiple novel epididymis-specific beta-defensin isoforms in humans and mice. J. Immunol. 169, 2516-2523. https:// doi.org/10.4049/jimmunol.169.5.2516

Yang D, Biragyn A, Hoover DM, Lubkowski J, Oppenheim JJ (2004): Multiple roles of antimicrobial defensins, cathelicidins, and eosinophil-derived neurotoxin in host defense. Annu. Rev. Immunol. 22, 181-215. https://doi.org/10.1146/annurev.immunol.22.012703.104603 